68 Smith B, Fowler DG, Freeman D, Bebbington P, Bashforth H, Garety P, et al Emotion and psychosis: links between depression, self-esteem, negative schematic beliefs and delusions and hallucinations. Schizophr Res 2006; 86 : 181-8.

69 O'Leary PJ. Men who were sexually abused in childhood: coping strategies and comparisons in psychological functioning. Child Abuse Negl 2009; 33: 471-9.

70 Cooke M, Peters E, Fannon D, Anilkumar APP, Aasen I, Kuipers E, et al. Insight, distress and coping styles in schizophrenia Schizoph Res 2007; 94: 12-22.
71 White R, Bebbington P, Pearson J, Johnson S, Ellis D. The social context of insight in schizophrenia. Soc Psychiatry Psychiatr Epidemiol 2000; 35: 500-7.

72 Holmes EA, Arntz A, Smucker MR. Imagery rescripting in cognitive behaviour therapy: images, treatment techniques and outcomes. J Behav Ther Exper Psychiatry 2007; 38: 297-305.

73 Read J, Hammersley P, Rudegeair T. Why, when and how to ask about childhood abuse. Adv Psychiatr Treat 2007; 13: 101-10.

74 Linden $\mathrm{M}$, Zehner $\mathrm{A}$. The role of childhood sexual abuse (CSA) in adult cognitive behaviour therapy. Behav Cogn Psychother 2007; 35: 447-55.

\title{
extra Letter to Father
}

\section{Franz Kafka}

At that time, and whenever possible at that time, I could have used some encouragement. I was, after all, already weighed down by your sheer physical presence. I remember, for example, how we often undressed together in the same changing-room. I was skinny, weakly, slight; you were strong, tall, broad. Even in the changing-room I felt pitiful, and what's more, not only in your eyes, but in the eyes of the entire world, for you were for me the standard by which everything was measured. When we stepped out of the changing-room in front of everyone - I holding your hand, a small skeleton, insecure, barefoot on the planks, afraid of the water, incapable of copying your swimming strokes, which you, with good intentions but actually to my profound shame, kept on demonstrating to me - then at such moments I was full of despair and all my bad experiences in all areas tallied marvelously. I felt happiest when you sometimes undressed first and I could stay in the changing-room alone and postpone the shame of appearing in public until you at last came looking for me and drove me out of the changing-room. I was grateful to you that you did not appear to notice my anguish; I was proud, too, of my father's body. Incidentally, this difference between us still exists much the same today.

Franz Kafka (1883-1924) is best known for his novels The Trial, The Castle, and the novella Metamorphosis. His Letter to Father was written in 1919 but never sent and it was published posthumously. This excerpt is from Letter to Father (pp. 15-16), translated by K. Reppin, published by Vitalis 1999.

Chosen by Femi Oyebode 